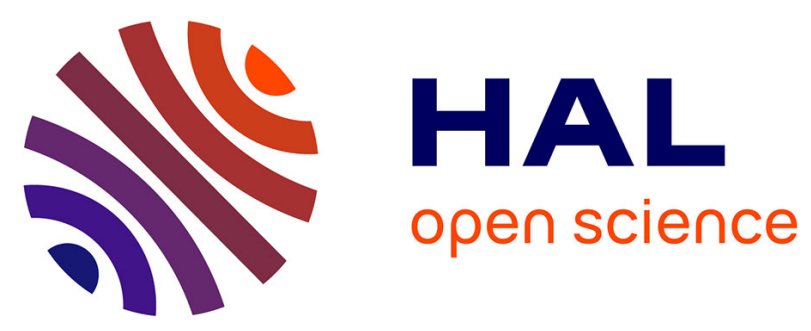

\title{
THE EXPANDING UNIVERSE OF COHESIN FUNCTIONS: A NEW GENOME STABILITY CARETAKER INVOLVED IN HUMAN DISEASE AND CANCER.
}

Linda Mannini, Stefania Menga, Antonio Musio

\section{To cite this version:}

Linda Mannini, Stefania Menga, Antonio Musio. THE EXPANDING UNIVERSE OF COHESIN FUNCTIONS: A NEW GENOME STABILITY CARETAKER INVOLVED IN HUMAN DISEASE AND CANCER.. Human Mutation, 2010, 31 (6), pp.623. 10.1002/humu.21252 . hal-00552379

\section{HAL Id: hal-00552379 \\ https://hal.science/hal-00552379}

Submitted on 6 Jan 2011

HAL is a multi-disciplinary open access archive for the deposit and dissemination of scientific research documents, whether they are published or not. The documents may come from teaching and research institutions in France or abroad, or from public or private research centers.
L'archive ouverte pluridisciplinaire HAL, est destinée au dépôt et à la diffusion de documents scientifiques de niveau recherche, publiés ou non, émanant des établissements d'enseignement et de recherche français ou étrangers, des laboratoires publics ou privés. 


\section{THE EXPANDING UNIVERSE OF COHESIN FUNCTIONS: A NEW GENOME STABILITY CARETAKER INVOLVED IN HUMAN DISEASE AND CANCER.}

\begin{tabular}{|r|l|}
\hline Journal: & Human Mutation \\
\hline Manuscript ID: & humu-2009-0533.R3 \\
\hline Wiley - Manuscript type: & Review \\
\hline Date Submitted by the \\
Author: & O2-Mar-2010 \\
\hline Complete List of Authors: & $\begin{array}{l}\text { Mannini, Linda; Istituto di Tecnologie Biomediche C.N.R., Unita' di } \\
\text { Pisa } \\
\text { Menga, Stefania; Istituto di Tecnologie Biomediche C.N.R., Unita' di } \\
\text { Pisa } \\
\text { Musio, Antonio; Istituto di Tecnologie Biomediche C.N.R., Unita' di } \\
\text { Pisa }\end{array}$ \\
\hline Key Words: & $\begin{array}{l}\text { Cohesin, Cornelia de Lange syndrome, Roberts syndrome , Genome } \\
\text { instability, Cancer }\end{array}$ \\
\hline \multicolumn{2}{|c}{} \\
\hline
\end{tabular}

\section{今 scholarONE" \\ Manuscript Central}


Humu-2009-0533

Review

Supporting Information for this preprint is available from the Human Mutation editorial office upon request (humu@wiley.com)

THE EXPANDING UNIVERSE OF COHESIN FUNCTIONS: A NEW GENOME STABILITY CARETAKER INVOLVED IN HUMAN DISEASE AND CANCER

Linda Mannini $^{1}$, Stefania Menga ${ }^{1}$, Antonio Musio ${ }^{1,2, *}$

1 Istituto di Tecnologie Biomediche, Consiglio Nazionale delle Ricerche, Pisa, Italy. 2 Istituto Toscano Tumori, Florence, Italy.

* Correspondence to: Antonio Musio, Istituto di Tecnologie Biomediche, Consiglio Nazionale delle Ricerche, Pisa, Italy

Tel: +390503152776

Fax: +390503153973

Email: antonio.musio@itb.cnr.it 


\begin{abstract}
Cohesin is responsible for sister chromatid cohesion, ensuring the correct chromosome segregation. Beyond this role, cohesin and regulatory cohesin genes seem to play a role in preserving genome stability and gene transcription regulation. DNA damage is thought to be a major culprit for many human diseases, including cancer. Our present knowledge of the molecular basis underlying genome instability is extremely limited. Mutations in cohesin genes cause human diseases such as the Cornelia de Lange syndrome and the Roberts syndrome/SC phocomelia, and all the cell lines derived from affected patients show genome instability. Cohesin mutations have also been identified in colorectal cancer. Here, we will discuss the human disorders caused by the alterations of cohesin function, with emphasis on the emerging role of cohesin as a genome stability caretaker.
\end{abstract}

Key words: Cohesin, genome instability, cancer, Cornelia de Lange syndrome, Roberts syndrome 


\section{OVERVIEW OF COHESIN FUNCTIONS}

\section{Canonical role of cohesin}

The discovery of the cohesin complex has led to a breakthrough in clarifying the "cohesive force" in play during mitosis in holding the sister chromatids together and ensuring correct chromosome segregation. Cohesin is composed of four subunits, a pair of SMC proteins, SMC1A (MIM\# 300040) and SMC3 (MIM\# 606062), which are members of the Structural Maintenance of Chromosome family, and two non-SMC proteins, RAD21/Scc1 (MIM\# 606462) and STAG/Scc3/Sa (Table 1) [Michaelis et al., 1997]. In vertebrates, there are two closely related Scc3 homologs, called STAG1 (MIM\# 604358) and STAG2 (MIM\# 604359) [Losada et al., 2000; Sumara et al., 2000]. In addition, a meiotic isoform is also present, named STAG3 (MIM\# 608489) [Prieto et al., 2001]. SMC proteins are characterized by a globular hinge domain flanked by two $\alpha$-helical domains (Figure 1A) which fold back on themselves at the hinge, forming a long antiparallel $\alpha$-helical coiled coil arm that brings the $\mathrm{N}$ and $\mathrm{C}$ termini together. The N-terminal contains the Walker A box (or P-loop) which binds ATP. The C-terminal holds the Walker B, binding to DNA. SMC1A and SMC3 dimerize at the hinge domains, forming a Vshaped structure through hydrophobic interactions. Basically, the cohesin complex acts as a tripartite ring in which SMC1A and SMC3 are connected by their hinge domains on one side, and RAD21 closes the ring by connecting the SMC1A and SMC3 head domains on the other side [Anderson et al., 2002; Haering et al., 2002] (Figure 2). The cohesin ring shape supports the model where interaction between cohesin and DNA is topological, the so-called "ring" or "embrace" model. According to this model, cohesin topologically encircles sister chromatids. The cohesin opens at the head domain followed by the sister chromatid entering the ring and 
becoming topologically entrapped when RAD21 locks the ring [Gruber et al., 2006; Gruber et al., 2003; Haering, et al., 2002; Haering et al., 2004; Ivanov and Nasmyth, 2007]. Transient dissociation of SMC hinge domains also seems to contribute towards the entry of DNA into the cohesin ring [Gruber et al., 2006]. Several alternative models, as well as the bracelet, oligomerization and snap models have been proposed as the molecular basis of sister chromatid cohesion [Diaz-Martinez et al., 2008; Guacci 2007; Huang et al., 2005; Milutinovich and Koshland, 2003]. These models have stimulated the research in this field and the true mechanism may be a combination of those proposed. The cohesin binding to chromatin is dynamic and occurs during the G1/S phase in the budding yeast or in the telophase of the previous cell cycle in vertebrates [Haering et al., 2004]. In yeast, cohesin binds along chromosome arms every 10-20 kb, while its density is higher at centromeric regions [Glynn et al., 2004; Kogut et al., 2009; Lengronne et al., 2004]. By contrast, in Drosophila the cohesin binding regions cover from a few kilobases up to $100 \mathrm{~kb}$ in length [Misulovin et al., 2008]. Though the chromosome arm dissociation process has yet to be fully understood, removal of cohesin begins in the prophase and is completed by the anaphase. In the first step, RAD21 and STAG subunits are phosphorylated by Polo-like kinase 1, causing the dissociation of the cohesin only along the chromosome arms [Hauf et al., 2005], while the bulk of centromeric cohesin remains unchanged [Waizenegger et al., 2000]. Once chromosomes are bi-oriented on the mitotic spindle at anaphase, cohesin is completely removed from chromosomes by the separase protein (MIM\# 604143) that cleaves RAD21, triggering sister chromatid disjunction. Initially, separase is inactivated through an association with securin (MIM\# 604147), which is released after degradation through the ubiquitin dependent proteolysis pathway [Hauf et al., 2001; Uhlmann et 
al., 2000]. This model suggests that cohesin, preserved from degradation by separase during the prophase, can be loaded onto chromatin just after the restoration of the nuclear membrane.

\section{Cohesin regulatory factors}

Cohesin interacts with several other proteins contributing towards its function (Table 1).

The loading of cohesin onto chromatin requires NIPBL activity (MIM\# 608667, homolog of fungal Scc2 and Drosophila Nipped-B). It has been speculated that NIPBL may be involved in the activation of SMC ATPase and chromatin remodeling [Arumugam et al., 2003; Jahnke et al., 2008]. PDS5A (MIM\# 613200) and PDS5B (MIM\# 605333) proteins are essential for the association of cohesin with chromatin and sister chromatid cohesion. Their amino acid sequences are conserved during evolution and are characterized by HEAT repeats which promote protein interaction [Panizza et al., 2000]. The presence of two PDS5 and STAG proteins renders possible the existence of four different types of cohesin containing either STAG1 or STAG2 and either PDS5A or PDS5B [Losada et al., 2005; Sumara et al., 2000]. Cohesin is also associated with WAPL; and like the PDS5 proteins, WAPL (MIM\# 610754) also contains motifs which promote protein-protein interaction. In fact, it has been shown that the FGF motifs of the WAPL protein allow the physical interaction with PDS5 and cohesin subunits [Shintomi and Hirano, 2009]. It is thought that WAPL is involved in the process of removing cohesin from chromatin [Gandhi et al., 2006; Kueng et al., 2006]. ESCO2 (MIM\# 609353) is involved in the establishment of bridges between chromatid sisters during the cell cycle [Ivanov et al., 2002; Skibbens et al., 1999; Toth et al., 1999]. It is also involved in the SMC3 acetylation [Heidinger-Pauli et al., 2009; Zhang et al., 2008a], necessary for replication fork progression [Terret et al., 2009]. Sororin (MIM\# 609374) is the last identified protein known to be involved in cohesin activity. 
Data regarding this protein are limited; however, it has been hypothesized that it is involved in sister chromatid cohesion [Rankin et al., 2005; Schmitz et al., 2007]. It is clear that cohesin activity is tightly regulated and it is possible that new regulatory proteins will be identified in the near future.

\section{NON CANONICAL ROLE OF COHESIN: GENE EXPRESSION REGULATION}

There is increasing experimental evidence suggesting that cohesin plays a part in the regulation of gene expression. The first proof that cohesin factors regulate gene expression comes from studies on the Drosophila Ultrabithorax and Cut genes which are involved in many developmental processes [Rollins et al., 1999]. In fact, the expression depends on Nipped-B which might facilitate the interaction between promoter and remote enhancers possibly by regulating chromosome architecture. Since Nipped-B acts as a cohesin regulatory protein, it was hypothesised that cohesin would have the same effect as Nipped-B on the gene expression regulation. Surprisingly, the inhibition of $S m c 1 a, R a d 21$ and $S a$ led to an increase of $C u t$ expression [Dorsett et al., 2005; Rollins et al., 2004]. These findings highlighted a possible role of cohesin as an insulator, inhibiting enhancer-promoter communication in $C u t$, and suggested that Nipped-B promotes enhancer-promoter interaction by altering cohesion binding to chromatin [Rollins et al., 2004] . Notably, cohesin contributes to the insulator activity of the CCCTC binding factor (CTCF), a zinc finger DNA-binding protein that is evolutionary conserved [Parelho et al., 2008; Rubio et al., 2008; Stedman et al., 2008; Wendt et al., 2008]. However, recent data suggest that the manner in which cohesin regulates gene expression is more complex. The fact that the depletion of either Rad21 or Smc3 in Zebrafish results in the reduced expression of Runx genes, involved in the activation of hematopoietic and neurogenic genes has been 
demonstrated [Horsfield et al., 2007]. Studies in Drosophila show that cohesin can exert opposing effects, both positive and negative, on gene expression [Schaaf et al., 2009]. These results are consistent with gene expression data obtained in Cornelia de Lange syndrome (CdLS; MIM\#s 122470, 300590, 610759) cell lines and in $\mathrm{Nipbl}^{+/-}$mutant mice where many genes are down- and up-regulated [Kawauchi et al., 2009; Liu et al., 2009b]. Beyond its role in sister chromatid cohesion, emerging data show that the activity of cohesin and cohesin regulatory factors is critical for the proper development of organisms by regulating gene expression in multiple ways.

Mutations in NIPBL, SMC1A and SMC3 cause CdLS while mutations in ESCO2 are associated with Roberts syndrome (RBS; MIM\# 268300) /SC phocomelia (MIM\# 269000) [Deardorff et al., 2007; Krantz et al., 2004; Musio et al., 2006; Schule et al., 2005; Tonkin et al., 2004; Vega et al., 2005]. CdLS and RBS are collectively termed "cohesinopathies" [reviewed in Liu and Krantz, 2008]. CdLS is the most frequent disease among those due to cohesion pathway defects. Though the molecular pathobiology of CdLS is largely unknown, it is noteworthy that the dysregulation of gene expression likely represents the underlying pathogenesis of CdLS. It has recently been discovered, by using a genome-wide approach to study gene expression, that alteration of a restricted number of genes which can be considered as CdLS biomarkers are capable of differentiating CdLS from non-CdLS samples. Their expression levels also correlate with the phenotypic severity of the disorder [Liu et al., 2009b]. In addition, small changes in Nipbl activity affect appropriate development in the $\mathrm{Nipbl}^{+-}$mouse model. In particular, gene expression profiling demonstrates that Nipbl deficiency leads to modest but significant transcriptional dysregulation of many genes [Kawauchi et al., 2009]. 
Cohesinopathy cell lines show both spontaneous and induced genome instability. In addition, mutations or dysregulation of cohesin and regulatory cohesin genes are associated with human cancer (see below). These observations suggest that the cohesin pathway may be involved in genome stability maintenance and tumorigenesis. This review focuses specifically on the emerging role of cohesin as a new genome stability caretaker involved in human disease and cancer.

\section{COHESIN AND GENOME INSTABILITY}

Genome instability has been discovered as one of the major factors responsible for human diseases, including cancer. It manifests as point mutations, gene amplifications, aneuploidies (i.e. the gain or loss of entire chromosomes), deletions and translocations. The genomic stability depends on an intricate machinery of DNA repair mechanisms, correct chromosome segregation pathways and the activation of cell cycle checkpoints in order to arrest cell cycle progression. The initial confirmation that cohesin is involved in genome stability came from studies in $S$. pombe. Sccl mutants are hypersensitive to DNA damage [Birkenbihl and Subramani, 1992], suggesting that cohesin plays an important function in the DNA damage response. In recent years, ample experimental evidence supports the notion that cohesin is also involved in genome stability maintenance in human cells. SMC1A was shown to be the target of the ATM kinase with phosphorylation of SMC1A-Ser957 and SMC1A-Ser966, occurring in an ATM dependent manner after ionizing irradiation [Kim et al., 2002; Yazdi et al., 2002]. Subsequently, it has been shown that NBS1 and BRCA1 are required for the recruitment of activated ATM at the sites of DNA double strand breaks, and that this process is necessary for the phosphorylation of SMC1A by ATM following irradiation [Kitagawa et al., 2004]. We showed that SMC1A phosphorylation 
can be ATM-independent, depending on the type of DNA damage. Moreover, we found that SMC1A is phosphorylated on Ser966 by ATR after replication stress induced by aphidicolin, while no phosphorylation occurred on Ser957 [Musio et al., 2005]. The finding that ATM is not involved in the SMC1A phosphorylation following replication stalling is not surprising because it seems to be specifically involved in response to irradiation [Kim et al., 2002; Yazdi et al., 2002]. These observations suggest that cohesin participates in two different pathways, triggering a specific response to different DNA damage types that challenge genome stability.

The heterodimer SMC1A-SMC3 is also a member of a mammalian protein complex, called recombination complex RC-1, which promotes DNA recombination [Jessberger et al., 1996; Stursberg et al., 1999]. There are three additional members belonging to the RC-1 complex: DNA ligase III, DNA polymerase $\varepsilon$, and unidentified structure-specific DNA endonuclease. It is thought that the RC-1 complex catalyses several recombination-related reactions such as the homology-dependent transfer of DNA between two dsDNA molecules, DNA single-strand reannealing, and the repair of gaps or deletions in dsDNA substrates [reviewed in Jessberger, 2002].

Following DNA damage, cohesin accumulates in a large $50 \mathrm{~kb}$ domain that surrounds the damage site [Strom et al., 2004; Unal et al., 2004] and SMC1A-SMC3 are phosphorylated [Kim, et al., 2002; Luo et al., 2008; Yazdi et al., 2002]. Cohesin's ability to establish cohesion de novo is essential for DNA damage repair [Strom, et al., 2004; Unal et al., 2004] and we found that fork stalling induced an increase in SMC1A synthesis levels [Musio et al., 2005]. These findings suggest that the cohesin increase and its accumulation can stabilize the broken sites, acting as scaffolding to improve the recruitment of DNA repair machinery. Furthermore, the 
phosphorylation of cohesin proteins may be required for activation of cell cycle checkpoints, allowing cell cycle arrest and DNA repair.

\section{COHESIN AND CANCER}

Genome instability is thought to play a pivotal role in the tumorigenic process and it is considered a hallmark of cancer cells. So far, only a limited number of genes thought to be involved in the maintenance of genome instability have been identified as having somatic mutations in human cancer. The recent finding that human colorectal cancers cells carry mutations in cohesin genes (Figure 3) further support the notion that cohesin is involved in genome instability and cancer. Eleven somatic mutations have been identified in more than 130 colorectal cancer cases. Six of them map to three core cohesin genes (SMC1A, SMC3 and $S T A G 3)$, four to a regulatory cohesin gene $(N I P B L)$ and one to $R N F 20$, a non related cohesin gene [Barber et al., 2008]. SMC1A and NIPBL account for 8 out of 10 mutations (Figures 3A, 3B). All $S M C 1 A$ mutations are missense (Supp. Table S1): c.1186T >C, c.1300C >T, c.1680C>G and c.3556G>A leading to Phe396Leu, Arg434Trp, Ile560Met and Val1186Ile changes, respectively. The first two mutations map to the coiled-coil domain, the third to the hinge domain and the last to carboxy terminal P-loop NTPase domain (Figure 3A). It is interesting to note that SMC1A mutations are only missense in both SMC1A-mutated CdLS patients (see below) and in cancer cells, suggesting that frameshift and nonsense mutations are lethal. The four mutations in NIPBL are: c.1435C>T, c.2967_2968 insT, c.1660C>T, c.5378T>A leading to Arg479X, Val992fsX, Gln664X and Met1793Lys changes (Figure 3B, Supp. Table S1). Finally, SMC3 and STAG3 show the mutations c.2635C >T and c.24117C >T (Supp. Table S1), which cause the Arg879X (Figure 3C) and Ile795Thr (Figure 3D) amino acid changes, respectively. 
The majority of these mutations are heterozygous nonsense mutations which disrupt protein function through the creation of stop codons. This finding raises the possibility that nonsense mutations might be more predisposed to cancer than missense mutations. These mutations could dysregulate cohesin activity by preventing correct protein association, by altering the SMC ATPase activity or affecting the dynamic displacement of cohesin from chromatin. Colorectal cancer cells are characterized by chromosomal instability, resulting in chromosome gain or loss. It is possible to argue that abnormal cohesion pathway activity leads to chromosome missegregation and chromosome instability. This hypothesis is supported by the observation that colorectal cancer cells exhibit up to 100-fold higher rates of missegregation than normal cells [Lengauer et al., 1997]. Therefore chromosomal instability in colorectal cancer cells could be a direct consequence of cohesin mutations.

In addition to core cohesin genes, there is increasing evidence also linking cohesin regulatory genes to tumorigenesis. The overexpression of WAPL correlates with the progression of cervical cancer malignancy (Table 1), and cells overexpressing WAPL develop tumors after injection into nude mice [Oikawa et al., 2004]. Separase is found to be significantly overexpressed in human breast cancer [Zhang et al., 2008b], osteosarcoma and prostate cancer (Table 1) [Meyer et al., 2009]. Its induction leads to premature separation of chromatids, lagging chromosomes with specific chromosome aneuploidies [Zhang, et al., 2008b]. Finally, ESCO2 is up-regulated in more aggressive melanomas [Ryu et al., 2007], Securin (also known as proto-oncogene pituitary tumor transforming gene, $P T T G$ ) is overexpressed in pituitary tumors [Zou et al., 1999] and $R A D 21$ is overexpressed in breast [Atienza et al., 2005; Oishi et al., 2007] and prostate cancer (Table 1) [Porkka et al., 2004]. ESCO2 and Securin promote cohesin function while WAPL and Separase antagonize this function. Therefore the fact that those genes are overexpressed in 
cancer suggests that cohesin and positive and negative regulatory proteins have a complex relationship with tumorigenesis. Indeed, in some cases these genes might act as oncogenes and in others as tumor suppressor genes. At present, the genetic factors which determine these opposite effects are not known.

Cancer is thought to be a multistep process in which abnormalities in proto-oncogenes and tumor suppressors predispose cells to the acquisition of many other genetic changes which are responsible for the acquisition of the full malignant phenotype. Cohesin could play an important role in genome instability and tumorigenesis, and chromosome aneuploidy due to defects in correct chromosome segregation could cause the loss of heterozygosity of tumor suppressor genes or the improper activation of proto-oncogenes. SMC1A associates with mitotic microtubules at the spindle pole, and SMC1A imbalance leads to multipolar spindles [Wong and Blobel, 2008]. Furthermore, the inhibition of cohesin genes by RNA interference or antisense oligonucleotide causes aneuploidy and micronuclei formation in dividing cells [Barber, et al., 2008; Musio et al., 2003]. These observations suggest that the association of SMC1A with microtubules is required for proper segregation, and its dysfunction leads to aneuploidy. In addition, cohesin mutations could dysregulate the expression of proto-oncogenes or tumor suppressor genes, triggering uncontrolled cell proliferation and the development of malignant cells. In human cells, cohesin depletion leads to changes in transcription at the imprinted H19/IGF2 locus [Nativio et al., 2009; Wendt et al., 2008]. Several lines of evidence support the hypothesis that the altered imprinting process at $H 19 / I G F 2$ locus is important in tumorigenesis [Feinberg, 1999; Pollak 2008]. It is therefore possible that defects in cohesin affect this imprinted domain and the genes within it. 


\section{COHESINOPATHIES AND GENOME INSTABILITY}

CdLS consists of characteristic facial features, hirsutism, gastroesophageal reflux, upper extremity malformations ranging from small hands to severe forms of oligodactyly and truncation of the forearms and mental retardation. Approximately $60 \%$ of CdLS probands carry a NIPBL mutation, most of which are point mutations or small insertions and deletions in coding regions or splice junctions. It is thought that these mutations produce either abnormal full length or truncated NIPBL proteins [Gillis et al., 2004]. A subset of CdLS probands carry mutations in the SMC1A and SMC3 genes [Deardorff et al., 2007; Musio et al., 2006]. SMC1A is responsible for $5 \%$ of CdLS cases whereas up until now only a single proband has been found to have a mutation in $S M C 3$. The $P D S 5 B$ gene could be an additional CdLS gene. Moreover, the $P d s 5 B$ knockout mice show several features reminiscent of the CdLS phenotype, and the genetic screening of a large cohort of CdLS patients allowed the identification of a patient carrying a mutation in the $P D S 5 B$ gene. However, the same mutation has been found in unaffected relatives making the role of this mutation in CdLS less clear [Zhang et al., 2009].

Collectively, a total of 23 mutations in the SMC1A and SMC3 core cohesion genes have been identified in CdLS (Supp. Table S1). All mutations are missense or small in-frame deletions (3 or 15 nucleotides deletion) [Deardorff et al., 2007; Liu et al., 2009a; Mannini et al., 2010]. The SMC3 amino acid change maps to the coiled coil domain (Figure 1B) whereas the SMC1A amino acid changes encompass all gene domains (Figure 1C) and do not affect the synthesis of the SMC1A protein [Liu et al., 2009a; Musio et al., 2006; Revenkova et al., 2009]. SMC1A maps to Xp11.2 which escapes X chromosome inactivation [Brown et al., 1995; Tsuchiya and Willard, 2000]. Both hemizygous male and heterozygous female CdLS patients have been identified [Deardorff et al., 2007; Liu et al., 2009a; Musio et al., 2006]; it is likely that SMC1A mutations 
act as a dominant negative in females [Liu et al., 2009a; Mannini et al., 2010; Revenkova et al., 2009].

RBS is an autosomal recessive developmental disorder characterized by pre-and post-natal growth retardation, tetraphocomelia, and craniofacial abnormalities. The causative gene of RBS is $E S C O 2$ which encodes a protein belonging to the highly conserved ECO1/CTF7 family of acetyltransferase which is involved in regulating sister chromatid cohesion [Vega et al., 2005]. Most ESCO2 mutations are expected to cause stop codons that result in truncated protein or mRNA instability due to nonsense-mediated mRNA decay [Gordillo et al., 2008]. All cohesinopathy cell lines are characterized by genome instability. A number of chromosomal rearrangements (balanced de novo translocations, duplications, deletions) have been reported in CdLS probands. The molecular characterization of the chromosomal rearrangement $\mathrm{t}(5 ; 13)(13.1 ; \mathrm{q} 12.1)$ allowed the identification of the NIPBL gene [Krantz et al., 2004]. CdLS cell lines show a statistically significant increase of both spontaneous and induced chromosome aberrations through genotoxic treatments such as irradiation and Mitomycin C [Revenkova et al., 2009; Vrouwe et al., 2007]. It is possible that dysregulation of cohesion activity triggers spontaneous genome instability and confers sensitivity to genotoxic treatments. Increased DNA damage seems to be a common feature of CdLS, suggesting that genome instability analysis and genotoxic agent treatments can be a useful diagnostic assay and can serve as a classification tool. We found that spontaneous genome instability analysis is able to discriminate among the different types of SMC1A mutations. In fact, CdLS patients carrying mutations in the head domain show higher frequency of chromosome aberrations than patients with mutations in the other domains [Revenkova et al., 2009].

RBS cell lines also display genome instability occurring as chromosome aneuploidies 
andmicronuclei formation, in addition to poor growth, reduced plating efficiency and lower density for confluent cultures [Jabs et al., 1991; Musio et al., 2004]. Cells from RBS patients exhibit a characteristic abnormality of their constitutive heterochromatin, described as precocious sister chromatid separation and puffing of the peri- and para-centromeric regions of chromosomes 1, 9 and 16. Less clear is the situation in CdLS; a study reported precocious sister chromatid separation [Kaur et al., 2005; Musio, et al., 2004], however more recent studies showed no cohesion defects in CdLS cell lines [Castronovo et al., 2009; Liu et al., 2009b; Revenkova et al., 2009; Tonkin et al., 2004; Vrouwe et al., 2007]. Similar observations have also been reported in $\mathrm{Nipbl}^{+/-}$mice [Kawauchi et al., 2009] and Nipped-B mutant fly [Rollins et al., 2004].

To date, no mutations have been identified in other cohesin pathway genes, their effect on cohesion can be inferred only by in vitro treatments. The depletion of WAPL prevents the resolution of sister chromatids, while its overexpression induces premature sister chromatid separation [Gandhi et al., 2006; Kueng et al., 2006]. The inactivation of Sororin leads to precocious sister chromatid separation [Schmitz et al., 2007] and the inhibition of Separase prevents sister chromatid separation leading to diplo- or quadruplochromosomes, indicating that sister chromatids were not disjoined in the previous cell cycle [Wirth et al., 2006]. Cohesinopathy probands have a low rate of cancer; up till now only a few cases of cancer have been described. In fact, four RBS patients developed oculomotor nerve cavernous angiomas, malignant melanoma and rhabdomyosarcoma [Feingold 1992; Ogilvy et al., 1993; Parry et al., 1986; Wenger et al., 1988] while some CdLS patients developed esophageal adenocarcinoma [reviewed in Kline et al., 2007]. It is possible to speculate that genomic instability in CdLS leads to the formation of certain tumors. Consistent with this notion is the observation that trisomy 21 
promotes the development of leukemia while the frequency of solid cancers is low in Down syndrome patients [Satgé et al., 1998]. Further epidemiologic studies will address the argument as to whether cohesinopathies lead to cancer development.

\section{CONCLUSION}

It is becoming clearer that the role of cohesin is not limited to holding sister chromatids together and ensuring correct chromosome segregation. More recent works have revealed that the universe of cohesin functions is rapidly expanding. In fact, cohesin is essential for gene expression regulation, cell cycle control, DNA damage response and genome stability maintenance. Mutations or dysregulation of cohesin and regulatory cohesin genes are associated to cohesinopathies and cancer. In addition, cohesinopathy cell lines show both spontaneous and induced genome instability, and in some cases it is responsible for the CdLS etiopathology. However, whether genome instability is a cause or a consequence of cohesinopathies is still open to debate. The dysfunction of cohesin pathways can cause missegregation, leading to chromosome aneuploidy, a hallmark of cancer cells, and improper activation or inhibition of proto-oncogene or tumor suppressor genes, respectively. However, it has recently been shown that aneuploidy represents a barrier towards cancer development [Williams et al., 2008]. It is possible that within a population of genomic-deregulated cells those with tolerated aneuploidy and high proliferative capacity are selected, leading to cancer development [Williams et al., 2008]. Altogether this evidence supports the intriguing notion that cohesin may represent a new genome stability caretaker in mammalian cells involved in human disease and cancer. It is becoming increasingly clear that cell lines derived from cohesinopathy probands suffer from 
\begin{tabular}{lll}
27 \\
\hline
\end{tabular}

defects in surveillance mechanisms, leading to genome instability. Cohesin defects and/or genome instability, in addition to dysregulation of gene expression resulting from mutations in cohesin genes could account for the growth retardation as well as developmental defects by affecting the number of cells in developing tissue, leading to specific cohesinopathy phenotypes.
\end{abstract}

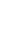

\title{
ACKNOWLEDGMENTS
}

This work is funded by grants from Istituto Toscano Tumori, Fondazione Cassa di Risparmio delle Provincie Lombarde and Consiglio Nazionale delle Ricerche (CNR, RSTL).

\section{REFERENCES}

Anderson DE, Losada A, Erickson HP, Hirano T. 2002. Condensin and cohesin display different arm conformations with characteristic hinge angles. J Cell Biol 156:419-424.

Arumugam P, Gruber S, Tanaka K, Haering CH, Mechtler K, Nasmyth K. 2003. ATP hydrolysis is required for cohesin's association with chromosomes. Curr Biol 13:1941-1953.

Atienza JM, Roth RB, Rosette C, Smylie KJ, Kammerer S, Rehbock J, Ekblom J, Denissenko MF. 2005. Suppression of RAD21 gene expression decreases cell growth and enhances cytotoxicity of etoposide and bleomycin in human breast cancer cells. Mol Cancer Ther $4: 361-368$.

Barber TD, McManus K, Yuen KW, Reis M, Parmigiani G, Shen D, Barrett I, Nouhi Y, Spencer F, Markowitz S, Velculescu VE, Kinzler KW, Vogelstein B, Lengauer C, Hieter P. 2008. 
Chromatid cohesion defects may underlie chromosome instability in human colorectal cancers. Proc Natl Acad Sci U S A 105:3443-3448.

Birkenbihl RP, Subramani S. 1992. Cloning and characterization of $\operatorname{rad} 21$ an essential gene of Schizosaccharomyces pombe involved in DNA double-strand-break repair. Nucleic Acids Res 20:6605-6611.

Brown CJ, Miller AP, Carrel L, Rupert JL, Davies KE, Willard HF. 1995. The DXS423E gene in Xp11.21 escapes X chromosome inactivation. Hum Mol Genet 4:251-255.

Castronovo P, Gervasini C, Cereda A, Masciadri M, Milani D, Russo S, Selicorni A, Larizza L. 2009. Premature chromatid separation is not a useful diagnostic marker for Cornelia de Lange syndrome. Chromosome Res 17:763-771.

Deardorff MA, Kaur M, Yaeger D, Rampuria A, Korolev S, Pie J, Gil-Rodriguez C, Arnedo M, Loeys B, Kline AD, Wilson M, Lillquist K, Siu V, Ramos FJ, Musio A, Jackson LS, Dorsett D, Krantz ID. 2007. Mutations in cohesin complex members SMC3 and SMC1A cause a mild variant of cornelia de Lange syndrome with predominant mental retardation. Am J Hum Genet 80:485-494.

Diaz-Martinez LA, Gimenez-Abian JF, Clarke DJ. 2008. Chromosome cohesion - rings, knots, orcs and fellowship. J Cell Sci 121:2107-2114.

Dorsett D, Eissenberg JC, Misulovin Z, Martens A, Redding B, McKim K. 2005. Effects of sister chromatid cohesion proteins on cut gene expression during wing development in Drosophila. Development 132:4743-4753.

Feinberg AP. 1999. Imprinting of a genomic domain of 11p15 and loss of imprinting in cancer: an introduction. Cancer Res 59:1743s-1746s. 
Feingold M. 1992. History of C-patient with SC-Roberts/pseudothalidamide syndrome. Am J Med Genet 43:898-899.

Gandhi R, Gillespie PJ, Hirano T. 2006. Human Wapl is a cohesin-binding protein that promotes sister-chromatid resolution in mitotic prophase. Curr Biol 16:2406-2417.

Gillis LA, McCallum J, Kaur M, DeScipio C, Yaeger D, Mariani A, Kline AD, Li HH, Devoto M, Jackson LG, Krantz ID. 2004. NIPBL mutational analysis in 120 individuals with Cornelia de Lange syndrome and evaluation of genotype-phenotype correlations. Am J Hum Genet 75:610-623.

Glynn EF, Megee PC, Yu HG, Mistrot C, Unal E, Koshland DE, DeRisi JL, Gerton JL. 2004. Genome-wide mapping of the cohesin complex in the yeast Saccharomyces cerevisiae. PLoS Biol 2:E259.

Gordillo M, Vega H, Trainer AH, Hou F, Sakai N, Luque R, Kayserili H, Basaran S, Skovby F, Hennekam RC, Uzielli ML, Schnur RE, Manouvrier S, Chang S, Blair E, Hurst JA, Forzano F, Meins M, Simola KO, Raas-Rothschild A, Schultz RA, McDaniel LD, Ozono K, Inui K, Zou H, Jabs EW. 2008. The molecular mechanism underlying Roberts syndrome involves loss of ESCO2 acetyltransferase activity. Hum Mol Genet 17:21722180.

Gruber S, Arumugam P, Katou Y, Kuglitsch D, Helmhart W, Shirahige K, Nasmyth K. 2006. Evidence that loading of cohesin onto chromosomes involves opening of its SMC hinge. Cell 127:523-537.

Gruber S, Haering CH, Nasmyth K. 2003. Chromosomal cohesin forms a ring. Cell 112:765-777. Guacci V. 2007. Sister chromatid cohesion: the cohesin cleavage model does not ring true. Genes Cells 12:693-708. 
Haering CH, Lowe J, Hochwagen A, Nasmyth K. 2002. Molecular architecture of SMC proteins and the yeast cohesin complex. Mol Cell 9:773-788.

Haering CH, Schoffnegger D, Nishino T, Helmhart W, Nasmyth K, Lowe J. 2004. Structure and stability of cohesin's Smc1-kleisin interaction. Mol Cell 15:951-964.

Hauf S, Roitinger E, Koch B, Dittrich CM, Mechtler K, Peters JM. 2005. Dissociation of cohesin from chromosome arms and loss of arm cohesion during early mitosis depends on phosphorylation of SA2. PLoS Biol 3:e69.

Hauf S, Waizenegger IC, Peters JM. 2001. Cohesin cleavage by separase required for anaphase and cytokinesis in human cells. Science 293:1320-1323.

Heidinger-Pauli JM, Unal E, Koshland D. 2009. Distinct targets of the Eco1 acetyltransferase modulate cohesion in S phase and in response to DNA damage. Mol Cell 34:311-321.

Horsfield JA, Anagnostou SH, Hu JK, Cho KH, Geisler R, Lieschke G, Crosier KE, Crosier PS. 2007. Cohesin-dependent regulation of Runx genes. Development 134:2639-2649.

Huang CE, Milutinovich M, Koshland D. 2005. Rings, bracelet or snaps: fashionable alternatives for Smc complexes. Philos Trans R Soc Lond B Biol Sci 360:537-542.

Ivanov D, Nasmyth K. 2007. A physical assay for sister chromatid cohesion in vitro. Mol Cell 27:300-310.

Ivanov D, Schleiffer A, Eisenhaber F, Mechtler K, Haering CH, Nasmyth K. 2002. Eco1 is a novel acetyltransferase that can acetylate proteins involved in cohesion. Curr Biol $12: 323-328$.

Jabs EW, Tuck-Muller CM, Cusano R, Rattner JB. 1991. Studies of mitotic and centromeric abnormalities in Roberts syndrome: implications for a defect in the mitotic mechanism. Chromosoma 100:251-261. 
Jahnke P, Xu W, Wulling M, Albrecht M, Gabriel H, Gillessen-Kaesbach G, Kaiser FJ. 2008. The Cohesin loading factor NIPBL recruits histone deacetylases to mediate local chromatin modifications. Nucleic Acids Res 36:6450-6458.

Jessberger R. 2002. The many functions of SMC proteins in chromosome dynamics. Nat Rev Mol Cell Biol 3:767-778.

Jessberger R, Riwar B, Baechtold H, Akhmedov AT. 1996. SMC proteins constitute two subunits of the mammalian recombination complex RC-1. Embo J 15:4061-4068.

Kaur M, DeScipio C, McCallum J, Yaeger D, Devoto M, Jackson LG, Spinner NB, Krantz ID. 2005. Precocious sister chromatid separation (PSCS) in Cornelia de Lange syndrome. Am J Med Genet A 138:27-31.

Kawauchi S, Calof AL, Santos R, Lopez-Burks ME, Young CM, Hoang MP, Chua A, Lao T, Lechner MS, Daniel JA, Nussenzweig A, Kitzes L, Yokomori K, Hallgrimsson B, Lander AD. 2009. Multiple organ system defects and transcriptional dysregulation in the Nipbl(+/-) mouse, a model of Cornelia de Lange Syndrome. PLoS Genet 5:e1000650.

Kim ST, Xu B, Kastan MB. 2002. Involvement of the cohesin protein, Smc1, in Atm-dependent and independent responses to DNA damage. Genes Dev 16:560-570.

Kitagawa R, Bakkenist CJ, McKinnon PJ, Kastan MB. 2004. Phosphorylation of SMC1 is a critical downstream event in the ATM-NBS1-BRCA1 pathway. Genes Dev 18:14231438.

Kline AD, Grados M, Sponseller P, Levy HP, Blagowidow N, Schoedel C, Rampolla J, Clemens DK, Krantz I, Kimball A, Pichard C, Tuchman D. 2007. Natural history of aging in Cornelia de Lange syndrome. Am J Med Genet C Semin Med Genet 145C:248-260.

John Wiley \& Sons, Inc. 
Kogut I, Wang J, Guacci V, Mistry RK, Megee PC. 2009. The Scc2/Scc4 cohesin loader determines the distribution of cohesin on budding yeast chromosomes. Genes Dev $23: 2345-2357$.

Krantz ID, McCallum J, DeScipio C, Kaur M, Gillis LA, Yaeger D, Jukofsky L, Wasserman N, Bottani A, Morris CA, Nowaczyk MJ, Toriello H, Bamshad MJ, Carey JC, Rappaport E, Kawauchi S, Lander AD, Calof AL, Li HH, Devoto M, Jackson LG. 2004. Cornelia de Lange syndrome is caused by mutations in NIPBL, the human homolog of Drosophila melanogaster Nipped-B. Nat Genet 36:631-635.

Kueng S, Hegemann B, Peters BH, Lipp JJ, Schleiffer A, Mechtler K, Peters JM. 2006. Wapl controls the dynamic association of cohesin with chromatin. Cell 127:955-967.

Lengauer C, Kinzler KW, Vogelstein B. 1997. Genetic instability in colorectal cancers. Nature 386:623-627.

Lengronne A, Katou Y, Mori S, Yokobayashi S, Kelly GP, Itoh T, Watanabe Y, Shirahige K, Uhlmann F. 2004. Cohesin relocation from sites of chromosomal loading to places of convergent transcription. Nature 430:573-578.

Liu J, Feldman R, Zhang Z, Deardorff MA, Haverfield EV, Kaur M, Li JR, Clark D, Kline AD, Waggoner DJ, Das S, Jackson LG, Krantz ID. 2009a. SMC1A expression and mechanism of pathogenicity in probands with X-Linked Cornelia de Lange syndrome. Hum Mutat $30: 1535-1542$.

Liu J, Krantz ID. 2008. Cohesin and human disease. Annu Rev Genomics Hum Genet 9:303320.

Liu J, Zhang Z, Bando M, Itoh T, Deardorff MA, Clark D, Kaur M, Tandy S, Kondoh T, Rappaport E, Spinner NB, Vega H, Jackson LG, Shirahige K, Krantz ID. 2009b. 
Transcriptional dysregulation in NIPBL and cohesin mutant human cells. PLoS Biol 7:e1000119.

Losada A, Yokochi T, Hirano T. 2005. Functional contribution of Pds5 to cohesin-mediated cohesion in human cells and Xenopus egg extracts. J Cell Sci 118:2133-2141.

Losada A, Yokochi T, Kobayashi R, Hirano T. 2000. Identification and characterization of SA/Scc3p subunits in the Xenopus and human cohesin complexes. J Cell Biol 150:405416.

Luo H, Li Y, Mu JJ, Zhang J, Tonaka T, Hamamori Y, Jung SY, Wang Y, Qin J. 2008. Regulation of intra-S phase checkpoint by ionizing radiation (IR)-dependent and IRindependent phosphorylation of SMC3. J Biol Chem 283:19176-19183.

Mannini L, Liu J, Krantz ID, Musio A. 2010. Spectrum and consequences of SMC1A mutations: the unexpected involvement of a core component of cohesin in human disease. Hum Mutat 31:5-10.

Meyer R, Fofanov V, Panigrahi A, Merchant F, Zhang N, Pati D. 2009. Overexpression and mislocalization of the chromosomal segregation protein separase in multiple human cancers. Clin Cancer Res 15:2703-2710.

Michaelis C, Ciosk R, Nasmyth K. 1997. Cohesins: chromosomal proteins that prevent premature separation of sister chromatids. Cell 91:35-45.

Milutinovich M, Koshland DE. 2003. Molecular biology. SMC complexes--wrapped up in controversy. Science 300:1101-1102.

Misulovin Z, Schwartz YB, Li XY, Kahn TG, Gause M, MacArthur S, Fay JC, Eisen MB, Pirrotta V, Biggin MD, Dorsett D. 2008. Association of cohesin and Nipped-B with 
transcriptionally active regions of the Drosophila melanogaster genome. Chromosoma 117:89-102.

Musio A, Mariani T, Montagna C, Zambroni D, Ascoli C, Ried T, Vezzoni P. 2004. Recapitulation of the Roberts syndrome cellular phenotype by inhibition of INCENP, ZWINT-1 and ZW10 genes. Gene 331:33-40.

Musio A, Montagna C, Mariani T, Tilenni M, Focarelli ML, Brait L, Indino E, Benedetti PA, Chessa L, Albertini A, Ried T, Vezzoni P. 2005. SMC1 involvement in fragile site expression. Hum Mol Genet 14:525-533.

Musio A, Montagna C, Zambroni D, Indino E, Barbieri O, Citti L, Villa A, Ried T, Vezzoni P. 2003. Inhibition of BUB1 results in genomic instability and anchorage-independent growth of normal human fibroblasts. Cancer Res 63:2855-2863.

Musio A, Selicorni A, Focarelli ML, Gervasini C, Milani D, Russo S, Vezzoni P, Larizza L. 2006. X-linked Cornelia de Lange syndrome owing to SMC1L1 mutations. Nat Genet $38: 528-530$.

Nativio R, Wendt KS, Ito Y, Huddleston JE, Uribe-Lewis S, Woodfine K, Krueger C, Reik W, Peters JM, Murrell A. 2009. Cohesin is required for higher-order chromatin conformation at the imprinted IGF2-H19 locus. PLoS Genet 5:e1000739.

Ogilvy CS, Pakzaban P, Lee JM. 1993. Oculomotor nerve cavernous angioma in a patient with Roberts syndrome. Surg Neurol 40:39-42.

Oikawa K, Ohbayashi T, Kiyono T, Nishi H, Isaka K, Umezawa A, Kuroda M, Mukai K. 2004. Expression of a novel human gene, human wings apart-like (hWAPL), is associated with cervical carcinogenesis and tumor progression. Cancer Res 64:3545-3549. 
Oishi Y, Nagasaki K, Miyata S, Matsuura M, Nishimura S, Akiyama F, Iwai T, Miki Y. 2007. Functional pathway characterized by gene expression analysis of supraclavicular lymph node metastasis-positive breast cancer. J Hum Genet 52:271-279.

Panizza S, Tanaka T, Hochwagen A, Eisenhaber F, Nasmyth K. 2000. Pds5 cooperates with cohesin in maintaining sister chromatid cohesion. Curr Biol 10:1557-1564.

Parelho V, Hadjur S, Spivakov M, Leleu M, Sauer S, Gregson HC, Jarmuz A, Canzonetta C, Webster Z, Nesterova T, Cobb BS, Yokomori K, Dillon N, Aragon L, Fisher AG, Merkenschlager M. 2008. Cohesins functionally associate with CTCF on mammalian chromosome arms. Cell 132:422-433.

Parry DM, Mulvihill JJ, Tsai SE, Kaiser-Kupfer MI, Cowan JM. 1986. SC phocomelia syndrome, premature centromere separation, and congenital cranial nerve paralysis in two sisters, one with malignant melanoma. Am J Med Genet 24:653-672.

Pollak M. 2008. Insulin and insulin-like growth factor signalling in neoplasia. Nat Rev Cancer $8: 915-928$.

Porkka KP, Tammela TL, Vessella RL, Visakorpi T. 2004. RAD21 and KIAA0196 at 8q24 are amplified and overexpressed in prostate cancer. Genes Chromosomes Cancer 39:1-10.

Prieto I, Suja JA, Pezzi N, Kremer L, Martinez AC, Rufas JS, Barbero JL. 2001. Mammalian STAG3 is a cohesin specific to sister chromatid arms in meiosis I. Nat Cell Biol 3:761766.

Rankin S, Ayad NG, Kirschner MW. 2005. Sororin, a substrate of the anaphase-promoting complex, is required for sister chromatid cohesion in vertebrates. Mol Cell 18:185-200. 
Revenkova E, Focarelli ML, Susani L, Paulis M, Bassi MT, Mannini L, Frattini A, Delia D, Krantz I, Vezzoni P, Jessberger R, Musio A. 2009. Cornelia de Lange syndrome mutations in SMC1A or SMC3 affect binding to DNA. Hum Mol Genet 18:418-427.

Rollins RA, Korom M, Aulner N, Martens A, Dorsett D. 2004. Drosophila nipped-B protein supports sister chromatid cohesion and opposes the stromalin/Scc3 cohesion factor to facilitate long-range activation of the cut gene. Mol Cell Biol 24:3100-3111.

Rollins RA, Morcillo P, Dorsett D. 1999. Nipped-B, a Drosophila homologue of chromosomal adherins, participates in activation by remote enhancers in the cut and Ultrabithorax genes. Genetics 152:577-593.

Rubio ED, Reiss DJ, Welcsh PL, Disteche CM, Filippova GN, Baliga NS, Aebersold R, Ranish JA, Krumm A. 2008. CTCF physically links cohesin to chromatin. Proc Natl Acad Sci U S A 105:8309-8314.

Ryu B, Kim DS, Deluca AM, Alani RM. 2007. Comprehensive expression profiling of tumor cell lines identifies molecular signatures of melanoma progression. PLoS One 2:e594.

Schaaf CA, Misulovin Z, Sahota G, Siddiqui AM, Schwartz YB, Kahn TG, Pirrotta V, Gause M, Dorsett D. 2009. Regulation of the Drosophila Enhancer of split and invected-engrailed gene complexes by sister chromatid cohesion proteins. PLoS One 4:e6202.

Schmitz J, Watrin E, Lenart P, Mechtler K, Peters JM. 2007. Sororin is required for stable binding of cohesin to chromatin and for sister chromatid cohesion in interphase. Curr Biol 17:630-636.

Schule B, Oviedo A, Johnston K, Pai S, Francke U. 2005. Inactivating mutations in ESCO2 cause SC phocomelia and Roberts syndrome: no phenotype-genotype correlation. Am J Hum Genet 77:1117-1128. 
Shintomi K, Hirano T. 2009. Releasing cohesin from chromosome arms in early mitosis: opposing actions of Wapl-Pds5 and Sgo1. Genes Dev 23:2224-2236.

Skibbens RV, Corson LB, Koshland D, Hieter P. 1999. Ctf7p is essential for sister chromatid cohesion and links mitotic chromosome structure to the DNA replication machinery. Genes Dev 13:307-319.

Satgé D, Sommelet D, Geneix A, Nishi M, Malet P, Vekemans M. 1998. A tumor profile in Down syndrome. Am J Med Genet 78:207-216.

Stedman W, Kang H, Lin S, Kissil JL, Bartolomei MS, Lieberman PM. 2008. Cohesins localize with CTCF at the KSHV latency control region and at cellular c-myc and H19/Igf2 insulators. Embo J 27:654-666.

Strom L, Lindroos HB, Shirahige K, Sjogren C. 2004. Postreplicative recruitment of cohesin to double-strand breaks is required for DNA repair. Mol Cell 16:1003-1015.

Stursberg S, Riwar B, Jessberger R. 1999. Cloning and characterization of mammalian SMC1 and SMC3 genes and proteins, components of the DNA recombination complexes RC-1. Gene 228:1-12.

Sumara I, Vorlaufer E, Gieffers C, Peters BH, Peters JM. 2000. Characterization of vertebrate cohesin complexes and their regulation in prophase. J Cell Biol 151:749-762.

Terret ME, Sherwood R, Rahman S, Qin J, Jallepalli PV. 2009. Cohesin acetylation speeds the replication fork. Nature 462:231-234.

Tonkin ET, Wang TJ, Lisgo S, Bamshad MJ, Strachan T. 2004. NIPBL, encoding a homolog of fungal Scc2-type sister chromatid cohesion proteins and fly Nipped-B, is mutated in Cornelia de Lange syndrome. Nat Genet 36:636-641. 
Toth A, Ciosk R, Uhlmann F, Galova M, Schleiffer A, Nasmyth K. 1999. Yeast cohesin complex requires a conserved protein, $\mathrm{Eco} 1 \mathrm{p}(\mathrm{Ctf} 7)$, to establish cohesion between sister chromatids during DNA replication. Genes Dev 13:320-333.

Tsuchiya KD, Willard HF. 2000. Chromosomal domains and escape from X inactivation: comparative X inactivation analysis in mouse and human. Mamm Genome 11:849-854.

Uhlmann F, Wernic D, Poupart MA, Koonin EV, Nasmyth K. 2000. Cleavage of cohesin by the CD clan protease separin triggers anaphase in yeast. Cell 103:375-386.

Unal E, Arbel-Eden A, Sattler U, Shroff R, Lichten M, Haber JE, Koshland D. 2004. DNA damage response pathway uses histone modification to assemble a double-strand breakspecific cohesin domain. Mol Cell 16:991-1002.

Vega H, Waisfisz Q, Gordillo M, Sakai N, Yanagihara I, Yamada M, van Gosliga D, Kayserili H, Xu C, Ozono K, Jabs EW, Inui K, Joenje H. 2005. Roberts syndrome is caused by mutations in ESCO2, a human homolog of yeast ECO1 that is essential for the establishment of sister chromatid cohesion. Nat Genet 37:468-470.

Vrouwe MG, Elghalbzouri-Maghrani E, Meijers M, Schouten P, Godthelp BC, Bhuiyan ZA, Redeker EJ, Mannens MM, Mullenders LH, Pastink A, Darroudi F. 2007. Increased DNA damage sensitivity of Cornelia de Lange syndrome cells: evidence for impaired recombinational repair. Hum Mol Genet 16:1478-1487.

Waizenegger IC, Hauf S, Meinke A, Peters JM. 2000. Two distinct pathways remove mammalian cohesin from chromosome arms in prophase and from centromeres in anaphase. Cell 103:399-410.

Wendt KS, Yoshida K, Itoh T, Bando M, Koch B, Schirghuber E, Tsutsumi S, Nagae G, Ishihara K, Mishiro T, Yahata K, Imamoto F, Aburatani H, Nakao M, Imamoto N, Maeshima K, 
Shirahige K, Peters JM. 2008. Cohesin mediates transcriptional insulation by CCCTCbinding factor. Nature 451:796-801.

Wenger SL, Blatt J, Steele MW, Lloyd DA, Bellinger M, Phebus CK, Horn M, Jaffe R. 1988. Rhabdomyosarcoma in Roberts syndrome. Cancer Genet Cytogenet 31:285-289.

Williams BR, Prabhu VR, Hunter KE, Glazier CM, Whittaker CA, Housman DE, Amon A. 2008. Aneuploidy affects proliferation and spontaneous immortalization in mammalian cells. Science 322:703-709.

Wirth KG, Wutz G, Kudo NR, Desdouets C, Zetterberg A, Taghybeeglu S, Seznec J, Ducos GM, Ricci R, Firnberg N, Peters JM, Nasmyth K. 2006. Separase: a universal trigger for sister chromatid disjunction but not chromosome cycle progression. J Cell Biol 172:847-860.

Wong RW, Blobel G. 2008. Cohesin subunit SMC1 associates with mitotic microtubules at the spindle pole. Proc Natl Acad Sci U S A 105:15441-15445.

Yazdi PT, Wang Y, Zhao S, Patel N, Lee EY, Qin J. 2002. SMC1 is a downstream effector in the ATM/NBS1 branch of the human S-phase checkpoint. Genes Dev 16:571-582.

Zhang B, Chang J, Fu M, Huang J, Kashyap R, Salavaggione E, Jain S, Kulkarni S, Deardorff MA, Uzielli ML, Dorsett D, Beebe DC, Jay PY, Heuckeroth RO, Krantz I, Milbrandt J. 2009. Dosage effects of cohesin regulatory factor PDS5 on mammalian development: implications for cohesinopathies. PLoS One 4:e5232.

Zhang J, Shi X, Li Y, Kim BJ, Jia J, Huang Z, Yang T, Fu X, Jung SY, Wang Y, Zhang P, Kim ST, Pan X, Qin J. 2008a. Acetylation of Smc3 by Eco1 is required for S phase sister chromatid cohesion in both human and yeast. Mol Cell 31:143-151.

Zhang N, Ge G, Meyer R, Sethi S, Basu D, Pradhan S, Zhao YJ, Li XN, Cai WW, El-Naggar AK, Baladandayuthapani V, Kittrell FS, Rao PH, Medina D, Pati D. 2008b. 
Overexpression of Separase induces aneuploidy and mammary tumorigenesis. Proc Natl Acad Sci U S A 105:13033-13038.

Zou H, McGarry TJ, Bernal T, Kirschner MW. 1999. Identification of a vertebrate sisterchromatid separation inhibitor involved in transformation and tumorigenesis. Science 285:418-422.

\section{FIGURE LEGENDS}

Figure 1. SMC core cohesin protein organization and CdLS. (A) Schematic organization of SMC proteins. They contain five distinct domains: N-terminal (or P-loop NTPase), a hinge motif flanked by two coiled coil regions and a C-terminal (or P-loop NTPase); (B) Mapping of the amino acid change identified in a CdLS patient in the SMC3 protein; (C) Localization onto the SMC1A protein of the twenty two amino acid mutations identified in CdLS.

Figure 2. Structure of cohesin complex. The somatic vertebrate core cohesin complex consists of two SMC subunits, namely SMC1A and SMC3, and two non SMC subunits, RAD21 and STAG. Each SMC subunit forms a rod shaped protein with a globular hinge domain at one end and an ATP nucleotide binding domain at the other. SMC1A and SMC3 are connected by their hinge domains on one side and the RAD21 closes the ring by connecting SMC1A and SMC3 head domains on the other side, creating a huge tripartite ring.

Figure 3. Cohesin and regulatory cohesin proteins and colorectal cancer. Localization of the four amino acid changes identified in both SMC1A (A) and NIPBL (B), and the single change 
1

2

3

4

5

6

7

8

9

10

11

12

13

14

15

16

17

18

19

20

21

22

23

24

25

26

27

28

29

30

31

32

33

34

35

36

37

38

39

40

41

42

43

44

45

46

47

48

49

50

51

52

53

54

55

56

57

58

59

60

detected in SMC3 (C) and STAG3 (D). The protein length is not in scale.

John Wiley \& Sons, Inc. 
Table 1. Components of cohesin pathway and their involvement in human diseases

\begin{tabular}{|c|c|c|c|}
\hline Gene & OMIM & Role & Disease \\
\hline SMC1A & 300040 & Core cohesin member & $\begin{array}{l}\text { CdLS } \\
\text { Colorectal cancer }\end{array}$ \\
\hline SMC3 & 606062 & Core cohesin member & $\begin{array}{l}\text { CdLS } \\
\text { Colorectal cancer }\end{array}$ \\
\hline$R A D 21$ & 606462 & Core cohesin member & $\begin{array}{l}\text { Breast cancer } \\
\text { Prostate cancer }\end{array}$ \\
\hline STAG1 & 604358 & Core cohesin member & \\
\hline STAG2 & 604359 & Core cohesin member & \\
\hline STAG3 & 608489 & Core cohesin member & Colorectal cancer \\
\hline$E S C O 2$ & 609353 & $\begin{array}{l}\text { Cohesin regulatory, } \\
\text { sister chromatid } \\
\text { cohesion }\end{array}$ & $\begin{array}{l}\text { RBS } \\
\text { Melanoma cancer }\end{array}$ \\
\hline NIPBL & 608667 & $\begin{array}{l}\text { Cohesin regulatory, } \\
\text { cohesin loading }\end{array}$ & $\begin{array}{l}\text { CdLS } \\
\text { Colorectal cancer }\end{array}$ \\
\hline PDS5A & 613200 & $\begin{array}{l}\text { Cohesin regulatory, } \\
\text { sister chromatid } \\
\text { cohesion }\end{array}$ & \\
\hline$P D S 5 B$ & 605333 & $\begin{array}{l}\text { Cohesin regulatory, } \\
\text { sister chromatid } \\
\text { cohesion }\end{array}$ & CdLS \\
\hline
\end{tabular}




\begin{tabular}{|c|c|c|c|}
\hline $\begin{array}{l}\text { PTTG1 } \\
\text { (Securin) }\end{array}$ & 604147 & $\begin{array}{l}\text { Cohesin regulatory, } \\
\text { sister chromatid } \\
\text { dissociation }\end{array}$ & Pituitary cancer \\
\hline $\begin{array}{l}\text { ESPL1 } \\
\text { (Separase) }\end{array}$ & 604143 & $\begin{array}{l}\text { Cohesin regulatory, } \\
\text { sister chromatid } \\
\text { dissociation }\end{array}$ & $\begin{array}{l}\text { Breast cancer } \\
\text { Osteosarcoma } \\
\text { Prostate cancer }\end{array}$ \\
\hline $\begin{array}{l}\text { CDCA5 } \\
\text { (Soronin) }\end{array}$ & 609374 & $\begin{array}{l}\text { Cohesin regulatory, } \\
\text { sister chromatid } \\
\text { cohesion }\end{array}$ & \\
\hline WAPL & 610754 & $\begin{array}{l}\text { Cohesin regulatory, } \\
\text { cohesin dissociation }\end{array}$ & Cervical Cancer \\
\hline
\end{tabular}


A

Figure 1

\begin{tabular}{|c|c|c|c|c|}
\hline $\begin{array}{c}\text { N terminal } \\
\text { P-loop NTPase }\end{array}$ & coiled coil & hinge & colled coil & $\begin{array}{c}\text { C terminal } \\
\text { P-loop NTPase }\end{array}$ \\
\hline
\end{tabular}
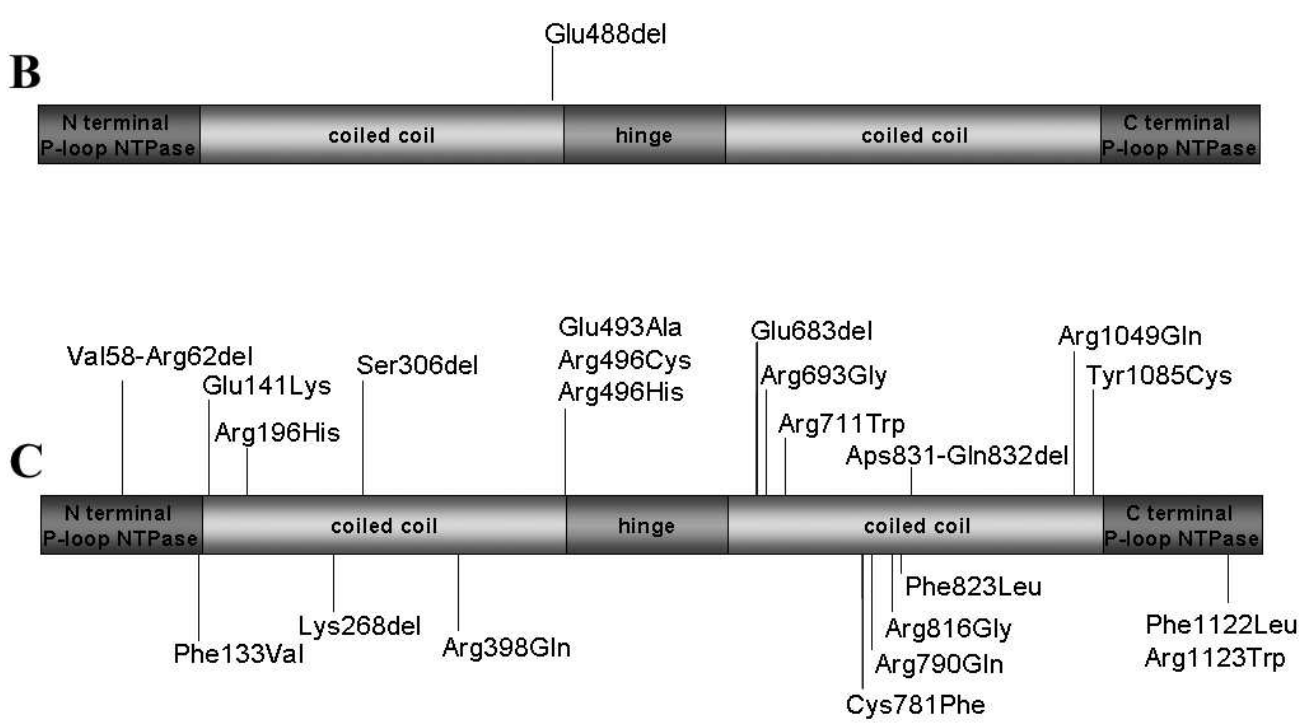

$130 \times 99 m m(200 \times 200$ DPI $)$

John Wiley \& Sons, Inc. 
Figure 2

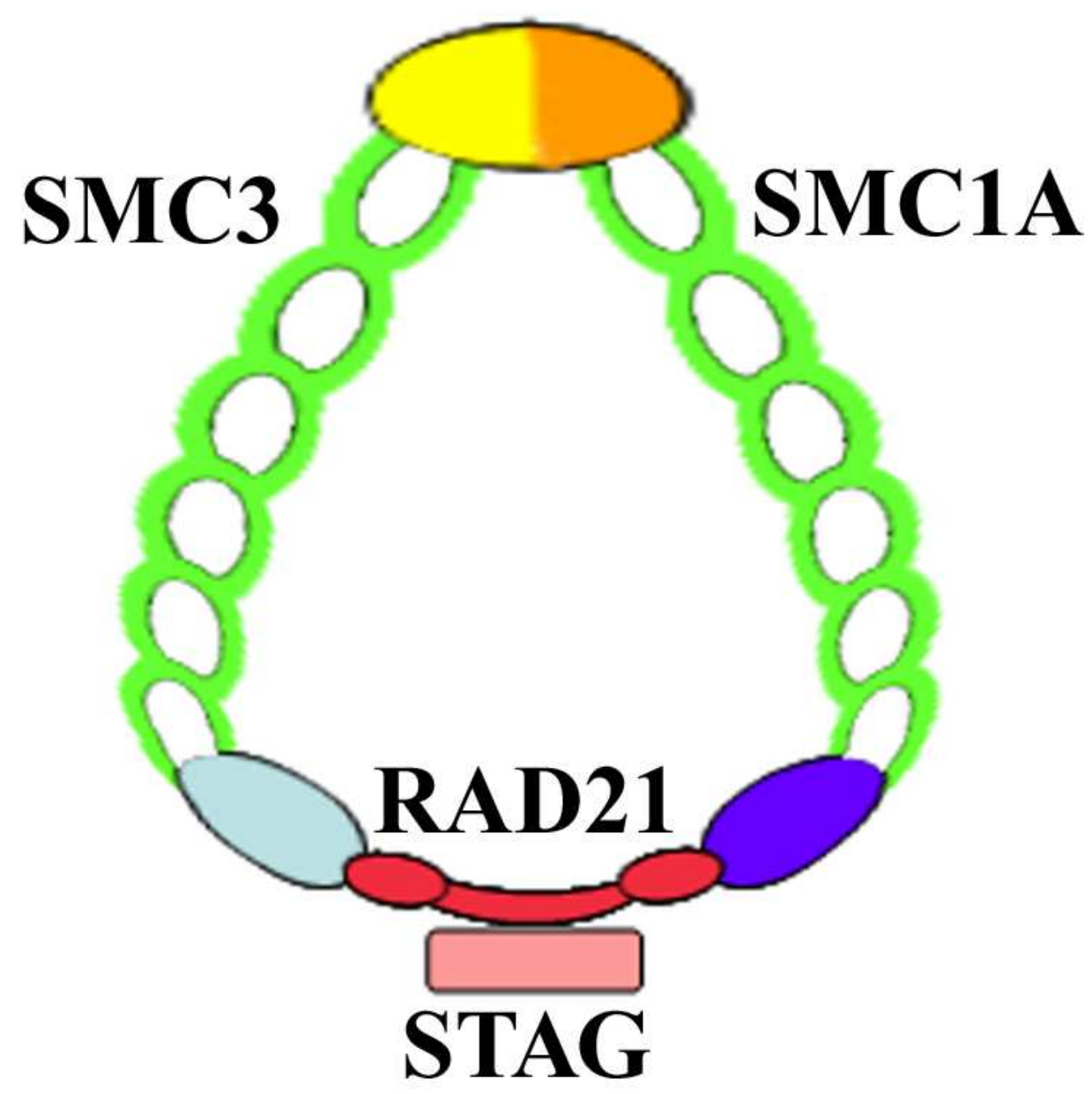

$99 \times 110 \mathrm{~mm}(200 \times 200 \mathrm{DPI})$

John Wiley \& Sons, Inc. 

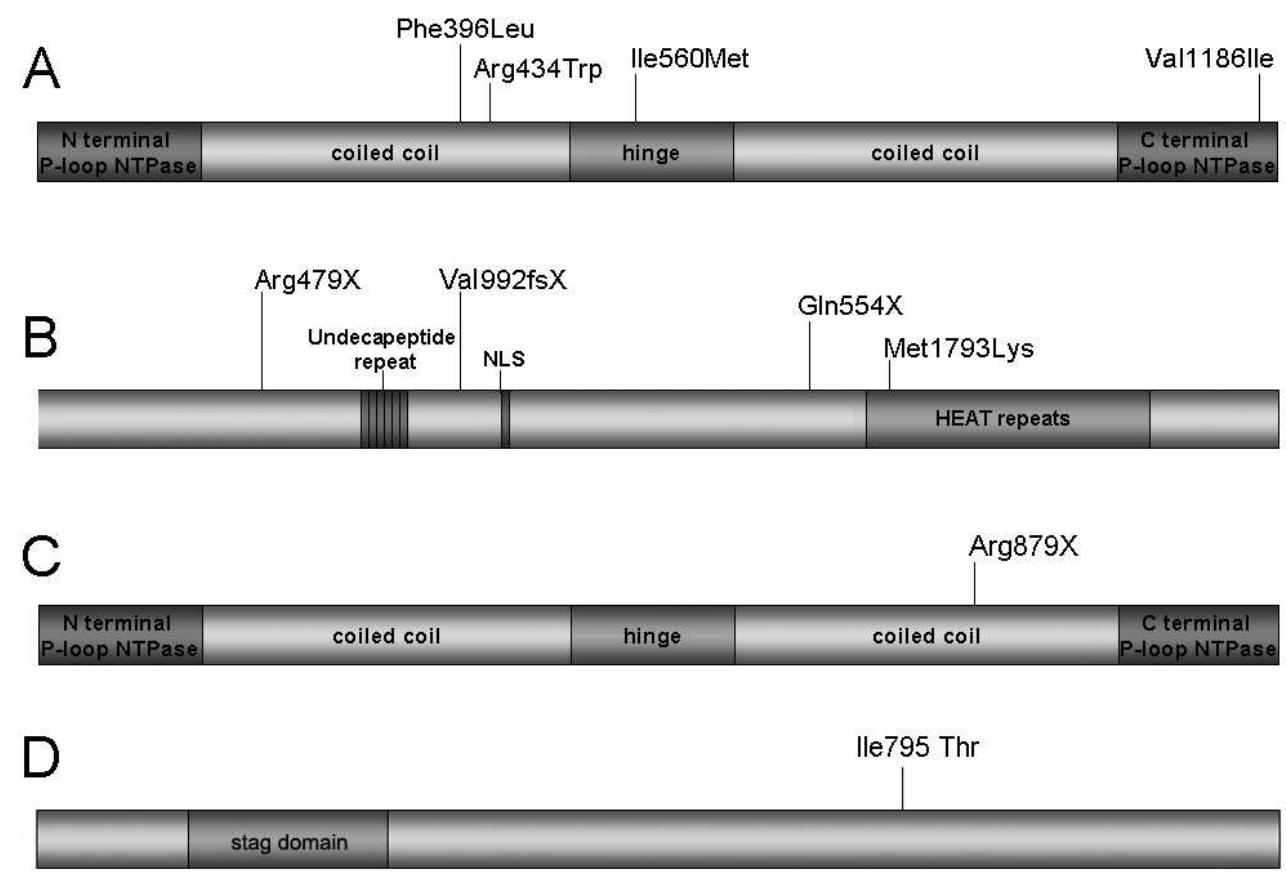

Figure 3

John Wiley \& Sons, Inc. 


\section{Supp. Table S1. Mutational spectrum of the SMC1A, SMC3, STAG3 and NIPBL in human disease}

\begin{tabular}{|c|c|c|c|}
\hline Gene & Nucleotide changes* & Effect on amino acid & Disease \\
\hline \multirow{26}{*}{ SMC1A } & c.173_187del15 & p.Val58-Arg62del & CdLS \\
\hline & c.397T $>\mathrm{G}$ & p.Phe133Val & CdLS \\
\hline & c. $421 \mathrm{G}>\mathrm{A}$ & p.Glu141Lys & CdLS \\
\hline & c. $587 \mathrm{G}>\mathrm{A}$ & p.Arg196His & CdLS \\
\hline & c.802_804del3 & p.Lys268del & CdLS \\
\hline & c.916_918del3 & p.Ser306del & CdLS \\
\hline & c. $1193 \mathrm{G}>\mathrm{A}$ & p.Arg398Gln & CdLS \\
\hline & c. $1478 \mathrm{~A}>\mathrm{C}$ & p.Glu493Ala & CdLS \\
\hline & c. $1486 \mathrm{C}>\mathrm{T}$ & p.Arg496Cys & CdLS \\
\hline & c. $1487 \mathrm{G}>\mathrm{A}$ & p.Arg496His & CdLS \\
\hline & c.2046_2048del3 & p.Glu683del & CdLS \\
\hline & c. $2077 \mathrm{C}>\mathrm{G}$ & p.Arg693Gly & CdLS \\
\hline & c. $2131 \mathrm{C}>\mathrm{T}$ & p.Arg711Trp & CdLS \\
\hline & c. $2342 \mathrm{G}>\mathrm{T}$ & p.Cys781Phe & CdLS \\
\hline & c.2369G $>A$ & p.Arg790Gln & CdLS \\
\hline & c. $2446 C>G$ & p.Arg816Gly & CdLS \\
\hline & c. $2467 \mathrm{~T}>\mathrm{C}$ & p.Phe823Leu & CdLS \\
\hline & c.2493_2495del3 & $\begin{array}{l}\text { p.Asp831- } \\
\text { Gln832del }\end{array}$ & CdLS \\
\hline & c.3146G $>A$ & p.Arg1049Gln & CdLS \\
\hline & c. $3254 \mathrm{~A}>\mathrm{G}$ & p.Tyr1085Cys & CdLS \\
\hline & c. $3364 \mathrm{~T}>\mathrm{C}$ & p.Phe1122Leu & CdLS \\
\hline & c. $3367 \mathrm{C}>\mathrm{T}$ & p.Arg1123Trp & CdLS \\
\hline & c. $1186 \mathrm{~T}>\mathrm{C}$ & p.Phe396Leu & Colorectal cancer \\
\hline & c. $1300 \mathrm{C}>\mathrm{T}$ & p.Arg434Trp & Colorectal cancer \\
\hline & c. $1680 \mathrm{C}>\mathrm{G}$ & p.Ile560Met & Colorectal cancer \\
\hline & c. $3556 \mathrm{G}>\mathrm{A}$ & p.Val1186Ile & Colorectal cancer \\
\hline \multirow[t]{2}{*}{ SMC3 } & c.1464_1466del3 & p.Phe488del & CdLS \\
\hline & c. $2635 \mathrm{C}>\mathrm{T}$ & p.Arg879X & Colorectal cancer \\
\hline STAG3 & c. $2384 \mathrm{~T}>\mathrm{C}$ & p.Ile795Thr & Colorectal cancer \\
\hline \multirow[t]{4}{*}{ NIPBL } & c. $1435 \mathrm{C}>\mathrm{T}$ & p.Arg479X & Colorectal cancer \\
\hline & c.2967_2968insT & p.Val992fsX & Colorectal cancer \\
\hline & c. $1660 \mathrm{C}>\mathrm{T}$ & p.Gln554X & Colorectal cancer \\
\hline & c. $5378 \mathrm{~T}>\mathrm{A}$ & p.Met1793Lys & Colorectal cancer \\
\hline \multicolumn{4}{|c|}{$\begin{array}{l}\text { * Nucleotide numbering reflects cDNA numbering with }+1 \text { corresponding to the A of the } \\
\text { ATG translation initiation codon in the reference sequences NM_006306.2 (for SMC1A), } \\
\text { NM_005445.3 (for SMC3), NM_012447.2 (for STAG3), NM_015384.3 (for NIPBL) } \\
\text { according to journal guidelines (www.hgvs.org/mutnomen). The initiation codon is codon } \\
\text { 1. }\end{array}$} \\
\hline
\end{tabular}

